\title{
A Systematic Review of Measures Used in Studies of Human Papillomavirus (HPV) Vaccine Acceptability
}

\author{
Jennifer D. Allen, DSc, MPH ${ }^{1,2}$, Gloria D. Coronado, $\mathrm{PhD}^{3}$, Rebecca S. Williams, MHS, \\ $\mathrm{PhD}^{4}$, Beth Glenn, PhD ${ }^{5}$, Cam Escoffery, PhD, MPH, CHES ${ }^{6}$, Maria Fernandez, $\mathrm{PhD}^{7}$, \\ Raegan A. Tuff, PhD, MPH ${ }^{8}$, Katherine M. Wilson, $\mathrm{PhD}, \mathrm{MPH}, \mathrm{CHES}^{8}$, and $\mathrm{Patricia}^{\mathrm{D}}$.lan \\ Mullen, DrPH ${ }^{7}$ \\ ${ }^{1}$ Dana-Farber Cancer Institute and Harvard Medical School, Boston, MA \\ ${ }^{2}$ Harvard Medical School, Boston, MA \\ ${ }^{3}$ Fred Hutchinson Cancer Research Center, Seattle, WA \\ ${ }^{4}$ University of North Carolina Center for Health Promotion and Disease Prevention, Chapel Hill, \\ NC \\ ${ }^{5}$ Department of Health Services, School of Public Health and Jonsson Comprehensive Cancer \\ Center, University of California, Los Angeles, CA \\ ${ }^{6}$ Rollins School of Public Health, Atlanta, GA \\ ${ }^{7}$ University of Texas School of Public Health, Houston, TX \\ ${ }^{8}$ Centers for Disease Control and Prevention, Atlanta, GA
}

\section{Abstract}

\begin{abstract}
Background-The recent proliferation of studies describing factors associated with HPV vaccine acceptability could inform health care providers in improving vaccine coverage and support future research. This review examined measures of HPV and HPV-vaccine knowledge, attitudes, beliefs and acceptability, described psychometric characteristics, and provided recommendations about their use.
\end{abstract}

Methods-A systematic search of Medline, CINAHL, PsychoInfo, and ERIC through May 2008 for English language reports of quantitative data from parents, young adults or adolescents yielded 79 studies.

Results-The majority of studies were cross-sectional surveys (87\%), self-administered (67\%), conducted before prophylactic vaccines were publicly available $(67 \%)$ and utilized convenience samples $(65 \%)$. Most measured knowledge (80\%), general attitudes about HPV vaccination $(40 \%)$, and willingness to vaccinate one's daughter (26\%). Two thirds did not report reliability or validity of measures. The majority did not specify a theoretical framework.

(C) 2010 Elsevier Ltd. All rights reserved

Corresponding Author: Jennifer Allen, DSc, MPH, Center for Community-Based Research Dana-Farber Cancer Institute 44 Binney Street Boston, MA 02115 Tel: 617 632-2269 Fax: 617 632-3161 jennifer_allen@dfci.harvard.edu.

Publisher's Disclaimer: This is a PDF file of an unedited manuscript that has been accepted for publication. As a service to our customers we are providing this early version of the manuscript. The manuscript will undergo copyediting, typesetting, and review of the resulting proof before it is published in its final citable form. Please note that during the production process errors may be discovered which could affect the content, and all legal disclaimers that apply to the journal pertain.

Disclaimer The findings and conclusions in this report are those of the author(s) and do not necessarily represent the official position of the Centers for Disease Control and Prevention. 
Conclusions-Use of a theoretical framework, consistent labeling of constructs, more rigorous validation of measures, and testing of measures in more diverse samples are needed to yield measurement instruments that will produce findings to guide practitioners in developing successful community and clinical interventions.

\section{Keywords}

human papillomavirus; vaccine; measures; methods; systematic review

\section{INTRODUCTION}

The recent availability of human papillomavirus (HPV) vaccines provides the potential for a major step forward in reducing the public health burden of the most common sexuallytransmitted infection in the United States (U.S.). Yet, this will only occur if there is widespread uptake of the vaccine. Behavioral interventions to ensure broad population coverage require an understanding of vaccine acceptability and the factors that predict it. Recently, there has been a proliferation of studies of this type. Several comprehensive reviews have summarized findings from published studies [1-4]. Across studies involving women, adolescents and parents, ratings of vaccine acceptability have generally been high. Nevertheless, numerous studies document concerns regarding issues of vaccine safety [5-7], efficacy [6-8], cost [9-13], and among parents, the potential impact of vaccination on adolescent sexual behaviors [14-16]. Findings regarding other potential salient factors in decision-making about vaccination, such as perceived severity and susceptibility to HPV infection, have been inconsistent [1,17].

Existing reviews cite difficulties in cross-comparison of study findings due to differences in study designs, sampling methods and populations, and in addition, differences in methods for assessing constructs related to vaccine acceptability [1-4]. In particular, the lack of standardized theoretical and operational definitions of constructs hypothesized to influence vaccine uptake creates concern about use of available data to guide interventions. In the absence of standardized methods for defining and measuring theoretical constructs, it is not possible to know if inconsistent findings are the result of differences in measurement or true variability across study populations. A high degree of measurement error could lead to erroneous findings, leading researchers either to abandon a line of inquiry that is worthy of further study, or to accept associations where none exist.

Given the early stage of this field and the rapid pace of new research, this is an opportune time to evaluate measures of HPV vaccine acceptability and to consider next steps to strengthen them. Thus, the aims of this paper are to: (1) systematically review measures used in published studies of HPV vaccine knowledge, attitudes and behaviors; (2) describe their characteristics and psychometric properties; and (3) provide recommendations to improve the measurement of constructs in future studies.

\section{METHODS}

We sought primary reports that presented quantitative data of HPV and HPV-vaccine related knowledge, attitudes, beliefs and acceptability. Studies included were those conducted in the English language and that sampled parents, other young adults or adolescents in an industrialized country. Qualitative studies, case reports, reviews, presentations of clinical guidelines and studies of health care providers were excluded.

A trained health services librarian with experience in conducting and documenting searches for systematic reviews searched the literature using Medline SilverPlatter, the Cumulative 
Index to Nursing and Allied Health Literature (CINAHL) SilverPlatter, PsychInfo CSA (Cambridge Scientific Abstracts) ILLUMINA and Educational Resource Information Center (ERIC). She selected the following search terms from Medical Subject Headings (MeSH): human papilloma virus OR HPV AND vaccine AND accept*, aware*, attitude*, belief*, behave*, decision, decide, intent*, know*, perceived*, percept*, risk*, sever*, uptake*, and will*. Next, she examined the thesauri of the other databases to ensure consistency across databases; adjustments were made as necessary to ensure standardization of search processes across databases. Published reports from January 1995 to May 2008 were identified and retrieved. Abstracts were reviewed for eligibility by three authors (JDA, MEF, RAT). When additional information was needed to determine eligibility, the full-text article was retrieved and reviewed.

A standardized data abstraction form was created based on a prior measurement review [18]. Coders (authors) abstracted information regarding study design, sample characteristics, application of a theoretical framework, constructs assessed, and characteristics of measures used to assess each construct. Determination of the constructs measured in each study was based on the best match with construct definitions and examples of measures described in authored papers posted by the Behavioral Research Program, Division of Cancer Control and Population Sciences, National Cancer Institute on its website [19].

To ensure consistency in coding, a standardized codebook was created. As a next step, all coders reviewed the same study and identified and resolved disagreements in coding. The codebook was thereafter revised. For each study included in the review, two authors independently coded and compared their results. Coding discrepancies within pairs were resolved through discussion with all co-authors. Once initial coding was completed, all authors reviewed the classification of measures for each of the constructs in each of the papers, and discussed any disagreements until consensus was reached. We opted for this group consensus method for coding, because of the large number of raters (eight) and the enormous variability in terms of how constructs were described and defined across studies. Data were entered into an online database; after cleaning, the data were downloaded into Excel files and evidence tables were constructed, organized by major construct categories (Table 1).

\section{RESULTS}

All citations ( $\mathrm{N}=1052)$ were reviewed for eligibility based on titles and abstracts. Of these 367 required full-text reviews; 79 studies met inclusion criteria.

\section{Study Characteristics}

Most (87\%) studies were cross-sectional, and approximately one-half were conducted in the U.S. (Table 1). Two-thirds of U.S. studies and 36\% of non-U.S. studies were conducted prior to approval of the first vaccine (June 2006), which necessitated framing questions about a hypothetical vaccine with unknown qualities that was not yet available. Most studies recruited participants from health care facilities (42\%) or colleges (30\%). Over half of them sampled women (58\%). Almost two-thirds used samples of convenience; random sampling was performed in $24 \%$ of studies. One third of studies included more than $75 \%$ white, nonHispanic participants. Sample sizes in most studies (88\%) exceeded 100; $30 \%$ had samples of 500 or more. The response rate was not reported or calculable in over $90 \%$ of all studies. Of the small minority of studies (18\%) that explicitly reported using an underlying theoretical or conceptual framework - the most common were the Health Belief Model [20], the Theory of Reasoned Action [21], or social cognitive theory [22]. 


\section{Constructs and measures}

Few studies reported the sources of measures employed. When reported, measures were generally described as having been developed by the authors. No studies that had adapted measures from another source described the nature or extent of adaptation. Thirty percent of the studies included reliability or validity information about the items that they used (see Table 2). Internal reliability (Cronbach's alpha) was reported in $20 \%$ of studies $[6,7,15,23-$ 36]. Test re-test reliability was reported in one study [31]. Weak tests of validity were performed in $16 \%$ of the studies $\left[5,8,23,24,{ }^{26},{ }^{29}, 30,34,37-39\right]$, primarily using expert opinion or qualitative evaluation. Two studies used focus groups to improve the content validity of survey items $[8,15]$; ten reported having had items reviewed by a panel of experts or tested among similar populations $\left[5,8,23,24,{ }^{29}, 30,34,37-39\right]$. Of the studies conducted in the U.S., only one developed an instrument for Spanish-speaking populations [37].

Awareness and knowledge of HPV were by far the most frequently assessed constructs ( $80 \%$ of studies), followed by attitudes toward vaccination (40\%), willingness for one's daughter to receive the vaccine (26\%), willingness to receive the vaccine oneself $(23 \%)$, perceived vulnerability to HPV (21\%), and perceived barriers to (16\%) and benefits (15\%) of receiving the vaccine. Details are provided below.

\section{Awareness and Knowledge of HPV and HPV vaccine}

Awareness and Knowledge of HPV-Awareness of HPV was assessed in 31 (38\%) of the studies, usually as a single item, such as "Have you ever heard of the human papillomavirus or HPV?" (Figure 1). Three-quarters of the studies assessed aspects of knowledge, including the health consequences of HPV infection $\left[5,8,10,15,{ }^{23}-29,37,40-73\right]$ (typically cervical cancer and genital warts), modes of viral transmission $\left[5,8,10,23,{ }^{24},{ }^{27}\right.$ $\left.32,37,40 \_43,45,46,49,50,52,54,55,57,63-65,68,72-75\right]$, and the asymptomatic nature of HPV infection $[5,23,25-29,37,40,45,46,48,54,56,57,63,65,68,69,73,75]$. Studies with items addressing knowledge of modes of viral transmission frequently assessed awareness that the virus is sexually-transmitted; seven specifically measured awareness that both men and women can acquire the virus $[5,27,50,63,65,72,75]$. Among studies assessing HPV health consequences, some also asked whether participants endorsed health problems that are not associated with HPV, such as infertility $[23,49,50,54,68]$, or "myths" such as whether the virus can be spread through toilet seats or by shaking hands with an infected person [24,27-29,42,62,64]. Nine studies [26-28,38,54,57,60,73,76] assessed some other aspect of HPV-related knowledge, such as the relationship between HPV and other sexually transmitted diseases, the need for continued Pap screening after vaccination, and the expected course of an HPV infection. Some studies asked participants about their sources of information about HPV infection, including where information was accessed and where they typically seek such information $[46,48,50,64,77,78]$. Information about measures in a number of studies was insufficient for us to determine which aspect of knowledge was assessed $[6,9,33,79]$.

Awareness of the HPV vaccine was assessed in eight studies (10\%), typically with a single item such as, "Have you ever heard of the HPV vaccine?" [25,28,38,44,50,55,57,60]. Eight studies assessed more in-depth aspects of knowledge about the vaccine $[5,8,33,38,44,47,50,77]$, including its efficacy $[5,38,44]$.

\section{Vaccine acceptability, intention and behavior}

Vaccine acceptability-Items were categorized as "vaccine acceptability" if they included the word "would," as in "Would you agree to vaccination..." or "Would you accept the vaccine..." Of 31 (39\%) studies that measured this construct, 21 measured parental acceptability of the vaccine for daughters $\left[5,7,8,12,{ }^{15},{ }^{25}, 34,38,39,44,53,58,60,61,80-86\right]$. 
Eighteen measured acceptability for oneself $\left[7,9,10,12,{ }^{25}, 34 \_36,38,48,50,61,{ }^{78},{ }^{80}, 84,85,87,88\right]$, and five inquired about the acceptability of vaccinating sons $[60,61,74,80,84]$.

The majority of measures of acceptability for daughters (73\%) were based on a single item, such as, "How likely would you be to vaccinate your daughter for HPV?" Items in four studies used an age referent $[6,38,78,81]$. Two studies that asked about vaccinating daughters mentioned a cost condition, including "only if reimbursed" [38] and "willingness to pay out of pocket" [25].

Vaccine acceptability for oneself was more often measured with multiple items (53\%). Response formats were typically Likert-type or dichotomous (32\% and 26\%, respectively). Two studies assessed vaccine acceptability using a single cost referent "if it were free" $[25,34]$. Two others assessed acceptability at graduated levels of cost $[12,88]$.

A small number of studies inquired about acceptability (for self or daughter) of an HPV vaccine that provided protection against different health outcomes, or had graduated levels of efficacy $[10,34,86,88]$. For example, two studies by the same author $[86,88]$ presented hypothetical scenarios that varied along four dimensions (mode of transmission, severity of infection, vaccine efficacy and availability of behavioral methods for prevention).

Participants rated the acceptability of each hypothetical vaccine. One assessed acceptability of a free HPV vaccine that prevented either HPV, cervical cancer or genital warts [34].

Vaccine intentions is defined as the "the amount of effort one is willing to exert to attain a goal" [89], "behavioral plans that...enable attainment of a behavioral goal" [21], or simply "proximal goals" [22]. Intentions were assessed in six (7\%) studies [6,31,33,54,55,74]; three asked about intention to vaccinate a daughter $[6,31,54,74]$ and three inquired about intention to vaccinate oneself $[33,54,55]$. One study included assessment of intentions for self and daughter [54], and one asked about both sons and daughters [74]. Item wording for intention included, "I intend to have my daughter receive the HPV vaccine." Only one study [33] included a time frame for obtaining the vaccine (i.e., "in the next year").

Vaccine uptake-Two studies assessed receipt of the HPV vaccine $[33,48]$. One included a single item, "Have you received the HPV vaccine?" with no clarification regarding number of doses [48]. In the other study [33], the item asked if the participant had received "at least one" dose of the HPV vaccine.

\section{Vaccine attitudes and beliefs}

Perceived severity of HPV reflects the "perception of negative consequences associated with an event or outcome" and is generally assessed by asking respondents to rate their agreement with the following question: "I believe that [HPV infection] is... 'severe' or 'serious' or 'significant.' [19]. This construct was assessed in 14 studies (18\%) $\left[6,7,9,15,{ }^{24},{ }^{25},{ }^{29},{ }^{32}, 33,35,48,57,77\right]$.

Items generally asked how upsetting or disruptive a diagnosis of HPV would be in terms of one's physical health, social relationships, or in finding a "long term sexual partner" $[7,9,35]$, whether there are medical complications of HPV infection [29], and whether HPV can be cured [24], or is life-threatening [24]. Some studies asked about shame associated with a diagnosis of HPV $[6,32,35,48,90]$. The referent in most of these studies was oneself; in one study it was also a partner [57], and in another, the respondent's children [6]. Three studies did not report specific wording $[15,25,33]$. Of the studies that assessed perceived severity of HPV, two also assessed perceived severity of cervical cancer [24,25]. One study assessed perceived severity of genital warts [77]. 
Perceived vulnerability to HPV is defined as the perceived likelihood of developing a health problem and is often assessed by asking "How likely is it you will get [HPV]" [19]. Items that address conditional perceived susceptibility typically ask about the likelihood of an event given that an action is/is not taken (e.g., "What would be the likelihood of getting [HPV] if you [did X]"), and items that address comparative perceived susceptibility typically ask "Compared to others your age, how likely is it you will get [HPV]." Perceived susceptibility was measured in 22 studies (28\%); of these, 17 had items referring to susceptibility of oneself $\left[7,9,10,24,{ }^{25},{ }^{27},{ }^{29},{ }^{33},{ }^{35}, 42,47,48,51,54,57,85,91\right]$ and five had items referring to susceptibility of a daughter $[6,15,25,39,85]$. General perceived susceptibility items asked respondents to rate their own or their daughter's chances of having HPV or getting it in the future $[6,9,15,35,39,42,57]$, or ability to avoid contracting it in the future [24]. One study addressed conditional perceived susceptibility, asking whether one's risk would be increased with riskier sexual activities [91]. Of the studies that assessed perceived vulnerability to HPV, three also assessed perceived vulnerability to cervical cancer in reference both to themselves $[19,24,25,54]$ and to their daughters [25].

Perceived benefits of the vaccine, defined as opinions about positive consequences of adopting a behavior [19], were assessed in 12 studies (15\%). Nearly one-half asked about general benefits, $[6,25,31,44,58]$ while others included more specific benefits, such as whether the HPV vaccine would help an individual to stay healthy [7,10,35], provide health benefits for oneself or one's partner [33,35], including protecting against future HPV infection [54], or preventing cervical cancer [10,50,54], genital warts [8,10,50], or penile cancer [8]. One study [10] also explored the extent to which being a role model for one's children was perceived as a benefit of vaccination.

Perceived barriers, defined as opinions about logistical or psychological costs of engaging in a behavior [19], were assessed in 13 studies $[7,9,10,12,15,25,33,35,38,53,54,61,77]$. These items differed from those under the "willingness to vaccinate" construct conditioned on cost (discussed above), as they did not assess cost in relation to acceptability or intentions. Cost items directly asked whether cost was a barrier [10,12,53], the importance of the vaccine being free or low cost $[9,25,38,54]$, or inquired about impact of health insurance coverage of the vaccine $[7,77]$. Other items assessed the impact of beliefs that getting "shots" would be difficult or painful $[9,33,54]$. Some assessed lack of knowledge about HPV or the vaccine as a barrier [33,61]. A few studies focused on ease of getting to a provider [25] or difficulty obtaining the vaccine $[33,35]$.

Thirteen (16\%) studies assessed perceived risks associated with the vaccine as a potential barrier by assessing general harmfulness of the vaccine $\left[5,7-9,15,{ }^{33}, 38,44,54,55\right]$, or concern about getting HPV from the vaccine itself $[8,10]$ Others assessed specific risks, such as short-term or long-term side effects [5,15,44,83], effects on adolescent development [5], and concerns about giving children too many vaccines $[15,61,83]$. Other risks included concerns about the vaccine influencing sexual behavior, for example, the extent to which vaccination would encourage earlier age at sexual debut $[8,12,15,44]$, diminish incentives for having safe sex [15,31], and promote acceptance of having more sexual partners [15,31].

Perceptions of who should receive vaccine-Seven studies (9\%) inquired about the appropriate recipients of the vaccine (e.g., different age groups of girls) $[5,9,12,38,54,61,78]$. Some asked about vaccinating children before they become sexually active $[5,12,54]$. Five studies also measured agreement with vaccinating males $[12,38,54,61,78]$ and two assessed attitudes toward vaccinating boys and girls [12,61]. Perceived effectiveness of the vaccine was evaluated in eight studies (10\%) $[5,7,8,12,25,31,39,54]$. Typically, effectiveness was assessed in terms of protection from 
cervical cancer $[5,8,12,25,31,39,54]$ or from specific types of HPV [5,7,8,25,54]. One [8] also asked about vaccine efficacy against penile cancer and genital warts.

Among other HPV attitudes and beliefs assessed were: perceived behavioral control in having a child vaccinated [31]; self-efficacy with regard to getting the vaccine once it became available [35] or ability to complete the three dose series [33]. Several other studies generally assessed the "importance" of the HPV vaccine $[9,10,39,83]$.

\section{Social Influences}

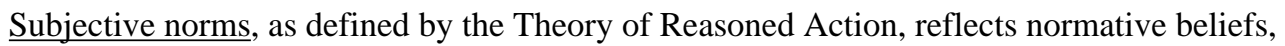
the perceptions of salient others' (e.g. spouse, friends) support for or opposition to a behavioral action, weighted by motivation to comply [92]. Typically, assessment of this construct involves pairs of questions. The first question assesses the respondent's perception of important others' attitudes toward a specified behavior. The second question then inquires about the degree to which important others' opinions influence the respondent's decision. The product of the question pairs (support multiplied by motivation to comply) reflects the full construct [19]. In this review, both aspects of subjective norms were measured in four studies $[7,31,55,74]$. Four studies measured normative beliefs only $[9,15,33,54]$, and three studies measured motivation to comply $[6,39,47]$, sometimes framed as a 'cue to action.'

Descriptive social norms, for the purposes of this paper, were defined as "an individual's perceptions about the acceptability of a behavior" derived from communications from network members or by portrayals of behavior in the mass media [19]. Social norms were measured in two studies [15,55]. Another form of social influence, provider recommendation of vaccination, was measured in ten studies $\left[6,7,9,12,{ }^{15},{ }^{25}, 36,39,47,54\right]$. These generally asked, "Has your health care provider recommended the HPV vaccine [for you/for your daughter]?"

\section{Conclusions}

We believe this to be the first systematic review of measurement instruments used in published studies to assess knowledge, attitudes and beliefs, and behaviors regarding the HPV vaccine. In a prior review, Tiro and others [68] examined items used to measure vaccine behaviors in national surveillance programs. Other reviews $[1,3]$ have synthesized findings of studies addressing HPV knowledge and attitudes or beliefs about the HPV vaccine. The existing body of literature on HPV vaccine acceptability has identified a variety of individual and social factors that may impact uptake. These studies represent a beginning from which future inquiries will benefit. Yet there remains a need for validated measures in the field. Accurate measurement tools are critical for the identification of accurate and salient factors associated with vaccination. Data from such measures is critical to the development of evidence-based interventions to ensure widespread uptake of the vaccine.

In our review, we found that the bulk of research has focused on awareness and knowledge about HPV. This is not surprising, because the causal relationship between HPV and cervical cancer is a relatively recent discovery, HPV vaccines have only been available for a short time, and the field is in an early stage of development [93]. At least two-thirds of existing U.S. studies and $36 \%$ of non-U.S. studies in this review were conducted prior to vaccine licensure. In these studies, questions related to vaccine attitudes and behaviors were framed in hypothetical terms (e.g., "If there were a vaccine available...") out of necessity. However, there is evidence to suggest that, under circumstances where benefits and potential harms are unknown-- such as in the case with a hypothetical vaccine scenario-- reported intention is not highly correlated with actual participation. For example, self-reported 
intention to participate in clinical trials is considerably lower than actual participation $[94,95]$. On a related note, some studies asked about willingness to vaccinate a child if the respondent were to have one (i.e., hypothetical child). The validity of using instruments and comparing findings from inquiries of hypothetical versus actual vaccines and hypothetical versus actual daughters is unknown. However, one study [38] reported findings from surveys conducted among adults, some of whom had daughters and/or sons and some of whom did not. With respect to willingness to vaccinate a daughter or son, notable differences were observed in responses from parents and non-parents. Specifically, those with children had higher levels of willingness to vaccine them. This suggests that caution should be used when interpreting results from such studies.

We observed inconsistency between authors' labels for what they were measuring and the theory-based definitions endorsed by the National Cancer Institute [19]. Many authors used the same measures to assess constructs that they variously called "vaccine intentions" and "vaccine acceptability." In addition, we noted a problem with conceptual overlap among constructs included in this review. Some studies combined items that addressed multiple constructs to form a single scale. The mixing of constructs within a single scale, and the overlap of items measuring disparate constructs can increase measurement error and diminished ability to compare findings across studies. Moreover, it diminishes the interpretability of psychometric properties of measures.

Of concern is that nearly $70 \%$ of the studies reported no information about reliability. Most frequently, internal consistency reliability (Cronbach's alpha) was the only attribute reported. This can be calculated following data collection, but it is a relatively weak indicator of measure quality. Reports of Cronbach's alpha were almost exclusively for knowledge scales, and they generally demonstrated adequate consistency, meaning that the items were measuring a single unidimensional latent construct. It does not mean that that they were measuring the construct they intended to measure, however, as we discuss below. A more important assessment would be stability of ratings over time, yet only one study assessed test-retest reliability [24].

Assessment of any form of validity was rare; only $16 \%$ of studies reported any information about this property. Content validity, assessed through expert opinion, was reported for some measures; other investigators pilot-tested instruments among individuals with similar demographic characteristics as their target audience. Yet, stronger forms of validation, including criterion and discriminant validity, were not reported for any of the measures in this review. In most cases, authors either developed items or adapted them from published research. This is understandable, given that there are not many existing measures specifically developed for HPV vaccination. However, reports provided little or no information about how they developed or adapted items, information that is considered essential in reporting guidelines [96-99]. Of great concern is that a substantial number of studies used single items to assess relatively complex constructs, which makes it unlikely that these measures fully represented the intended construct. As such, information to guide investigators seeking to identify standardized measures or those with documented psychometric qualities for future research is limited.

The absence of information about potential cultural influences on HPV vaccine behaviors is also particularly notable, since these factors could play a crucial role in the development of vaccine intervention messages or the selection of channels of intervention delivery. A large portion of studies were conducted among college students and predominantly non-Hispanic White samples with relatively high levels of education. Black individuals represented onequarter or more of the samples in only five studies [8,25,33,34,37]. And, few studies included meaningful numbers of Latinas, women in rural locations, and those with lower 
levels of income and education [100], although these groups are disproportionately affected by HPV-associated illnesses. Among the articles we reviewed, only one reported developing a survey in both English and Spanish [37]. No studies reported the literacy level required to read the measures. The historically low uptake of vaccines in high risk populations warrants a concentrated effort toward the development of measures that will provide the necessary data to develop culturally relevant and linguistically appropriate interventions.

\section{Recommendations}

We offer several recommendations about development and reporting of measures, in hopes of motivating efforts toward the development and use of standardized measures with demonstrated validity and reliability. We begin with recommendations that are applicable to measurement of any study topic, then address some of the unique challenges of measuring acceptability and uptake of a new vaccine for a sexually transmitted disease.

As this field of research advances, it is critical that increased attention be focused on the development of measures so as to improve our understanding of factors that influence vaccine uptake. One step toward this goal would be greater use and explication of conceptual underpinnings of studies. Theory provides conceptual clarity for construct definitions, guides the designation of primary and secondary outcomes, can identify potential mediating and moderating factors, determine the timing of data collection, and dictate analytic strategies. Greater use of standardized construct definitions, for example as provided by the NCI website, would facilitate consistent measurement and enable greater comparability of findings across studies. The majority of theory-based studies included in this review applied the Health Belief Model and Theory of Reasoned Action, which focus heavily on the influence of individual perceptions and behavior. We advocate use of a conceptual framework that also considers the influence of interpersonal relationships, institutional and health-system factors, mass media, as well as vaccine policy [101]. For this, an ecological model, such as that described by McElroy and colleagues [102], can facilitate a more comprehensive understanding of vaccine attitudes and behaviors in a broader context [101]. Moreover, it may be useful to draw from theories of informed decision making, such as those developed by O'Connor [103], as well as decision sciences [104].

As noted, the majority of studies to date focused on HPV knowledge. As knowledge levels increase over time and with greater exposure to information about the vaccine [3], additional emphasis on attitudes and beliefs is warranted, particularly because knowledge is a weak predictor of behavior [105]. While it is likely that intervention efforts will likely focus on disseminating knowledge, we recommend additional study of the specific domains of knowledge required for informed decision-making, such as vaccine risks, benefits, limitations, as well as predicted efficacy and duration of effect.

Exploration of other constructs, such as intention and actual behavior, will also be increasingly important as awareness of HPV and the vaccine increases. As time passes, it will be critical to measure compliance with the three-dose series and with cervical cancer screening recommendations, particularly among groups that suffer a disproportionate burden of HPV-associated illness. In addition, studies are needed to better understand provider knowledge and behaviors. Much attention has focused on individual or parental characteristics that influence decisions to vaccinate. However, if a provider does not recommend vaccination, individual and parental decisions may be inconsequential. It will also be important to understand the impact of direct-to-consumer advertising, extensive media attention, and controversial legislative efforts to mandate vaccine coverage on HPVrelated attitudes and behaviors. While study of HPV vaccine uptake presents unique challenges given this context, studies of uptake of the Hepatitis B vaccine [106,107] and 
acceptability of future HIV vaccines [108,109] share similarities (e.g., sexual transmission) and could provide insights for the development of standardized measurements.

When necessary to develop original measures, review of items by a panel of experts [110], cognitive interviewing [111], and pilot testing of items among the intended audience [110] is recommended to optimize content validity, minimize "floor" or "ceiling" effects, and to improve understandability. Such efforts to develop questions to assess theoretically-derived constructs associated with HPV vaccine uptake are currently underway [112]. In addition, because HPV is a sexually-transmitted virus and some parents are concerned that vaccination may result in unsafe sexual behaviors, sensitivity is also needed in the development of items to assess vaccine decisions. To reduce the potential for social desirability bias or underreporting, questions should be constructed with neutral wording, could incorporate question stems that indicate researcher impartiality (e.g., "Many people believe that there are advantages and disadvantages to HPV vaccination"), or might utilize open-ended response options (e.g., "What are your concerns about vaccinating your daughter?") [110].

Overall, inclusion of more detail about measures in study reports such as information about methods used to develop measures, changes made to existing measures if used, as well as strategies employed to assess validity and reliability would facilitate methodologic advancements. Reporting standards, CONSORT (Consolidated Standards of Reporting Trials) [96,97], TREND (Transparent Reporting of Evaluations with Non-Randomized Designs) [98], and STROBE [99] provide detailed guidance for reporting important details about study methods and results for the respective types of study they address. Greater consideration and use of these guidelines would ensure the availability of information needed to assess strengths and limitations of research in this field. Moreover, establishing a central repository for measures would aid investigators in identifying tested items, the use of which would facilitate cross-comparison of study findings. Agencies funding such research ought to collaborate to create this repository and consider requiring this sharing function for newly funded research.

We also recommend more attention to the development and testing of measures for highpriority audiences. While women in the HPV vaccine "catch-up" age group (i.e., 13-26 years of age) are currently an important target audience, parents will likely be the primary audience at whom future vaccination efforts are directed, particularly those who are members of 'minority' racial and ethnic groups, individuals with low literacy skills, and nonEnglish speakers. These groups experience disparities to access of health information and may also have diminished access to vaccine [113]. Notably, rates of initial vaccination appear to be higher among those with lower levels of income and education, as well as Hispanics [114]. This may be due to reduced financial barriers to the vaccine because of the federal Vaccine for Children Program, which makes vaccine available free-of-cost. Nevertheless, we believe that these groups remain a high priority for intervention efforts because of diminished access to information about the vaccine [113], lower rates of completion of the three-dose series [115], and unremitting disparities in cervical cancer incidence and mortality [116]. Development of valid and reliable instruments to assess knowledge, attitudes and behaviors across audiences that are diverse with respect to race/ ethnicity, language, literacy levels-- as well as gender [117] now that the vaccine is available to boys-- will require time, resources, and a concerted effort among investigators. In the meantime, giving research consumers sufficient information with which to assess the quality of measures is essential for judicious application of study findings.

Evidence-based interventions for HPV vaccination are needed. Such interventions will be guided by the literature on factors associated with vaccine intentions and acceptability. 
While the currently-available literature provides the preliminary foundation from which to launch such efforts, additional development of measures to assess factors that influence vaccine decision-making is needed to further advance this goal.

\section{Acknowledgments}

Research for this publication was supported by the Centers for Disease Control and Prevention (CDC) and the National Cancer Institute (NCI) cooperative agreements for the Cancer Prevention and Control Research Networks (CPCRN) at Emory University School of Public Health (1-U48 DP00043); Harvard School of Public Health/Boston School of Public Health (1-U48-DP000064); Morehouse School of Medicine, Prevention Research Center (1-U48DP00056); University of California at Los Angeles School of Public Health (1-U48-DP00059); University of North Carolina at Chapel Hill, Center for Health Promotion and Disease Prevention (1-U48-DP000056); University of Texas School of Public Health ((1-U48-DP-000057); and University of Washington School of Public Health and Community Medicine/ Fred Hutchinson Cancer Research Center (1-U48-DP000050).

We thank Wanda Anderson, Roshan Bastani, Erin Breen, Noel Brewer, Emily Chasson, Sandy Dunstan, Sarah Eichenberger, Karen Glanz, Michael London, Nicole Neibaur, Hallary Patch, Byron Raines, Jillian Varley, Vicky Taylor, Laura Tom, Guillermo Tortolero-Luna, for their contributions to this work.

\section{REFERENCES}

[1]. Brewer NT, Fazekas KI. Predictors of HPV vaccine acceptability: a theory-informed, systematic review. Prev Med 2007;45(2-3):107-14. [PubMed: 17628649]

[2]. Black L, Zimet GD, Short MB, Sturm L, Rosenthal SL. Literature review of human papillomavirus vaccine acceptability among women over 26 years. Vaccine 2009;27(11):166873. [PubMed: 19195491]

[3]. Klug SJ, Hukelmann M, Blettner M. Knowledge about infection with human papillomavirus: a systematic review. Prev Med 2008;46(2):87-98. [PubMed: 17942147]

[4]. Zimet GD. Improving adolescent health: focus on HPV vaccine acceptance. J Adolesc Health 2005;37(6 Suppl):S17-23. [PubMed: 16310137]

[5]. Brabin L, Roberts SA, Farzaneh F, Kitchener HC. Future acceptance of adolescent human papillomavirus vaccination: A survey of parental attitudes. Vaccine 2006;24(16):3087-94. [PubMed: 16500736]

[6]. Dempsey AF, Zimet GD, Davis RL, Koutsky L. Factors that are associated with parental acceptance of human papillomavirus vaccines: A randomized intervention study of written information about HPV. Pediatrics 2006;117(5):1486-93. [PubMed: 16651301]

[7]. Gerend MA, Lee SC, Shepherd JE. Predictors of human papillomavirus vaccination acceptability among underserved women. Sex transm Dis 2007;34(7):468-71. [PubMed: 17139233]

[8]. Davis K, Dickman ED, Ferris D, Dias JK. Human papillomavirus vaccine acceptability among parents of 10- to 15-year-old adolescents. J Low Genit Tract Dis 2004;8(3):188-94. [PubMed: 15874862]

[9]. Boehner CW, Howe SR, Bernstein DI, Rosenthal SL. Viral sexually transmitted disease vaccine acceptability among college students. Sex transm Dis 2003;30(10):774-8. [PubMed: 14520177]

[10]. Ferris DG, Waller JL, Owen A, Smith J. Midadult women's attitudes about receiving the prophylactic human papillomavirus vaccine. J Low Genit Tract Dis 2007;11(3):166-72. [PubMed: 17596762]

[11]. Gerend MA, Barley J. Human papillomavirus vaccine acceptability among young adult men. Sex Transm Dis 2009;36(1):58-62. [PubMed: 18830138]

[12]. Sauvageau C, Duval B, Gilca V, Lavoie F, Ouakki M. Human papilloma virus vaccine and cervical cancer screening acceptability among adults in Quebec, Canada. BMC Public Health 2007;7:304. [PubMed: 17961209]

[13]. Wong LP. Young multiethnic women's attitudes toward the HPV vaccine and HPV vaccination. Int J Gynaecol Obstet 2008;103(2):131-5. [PubMed: 18768178]

[14]. Kahn JA, Ding L, Huang B, Zimet GD, Rosenthal SL, Frazier AL. Mothers' intention for their daughters and themselves to receive the human papillomavirus vaccine: a national study of nurses. Pediatrics 2009;123(6):1439-45. [PubMed: 19482752] 
[15]. Marlow LA, Waller J, Wardle J. Parental attitudes to pre-pubertal HPV vaccination. Vaccine 2007;25(11):1945-52. [PubMed: 17284337]

[16]. Zimet GD, Perkins SM, Sturm LA, Bair RM, Juliar BE, Mays RM. Predictors of STI vaccine acceptability among parents and their adolescent children. J Adolesc Health 2005;37(3):179-86. [PubMed: 16109336]

[17]. Fernandez M, Allen JD, Mistrey R, Kahn JA. Integrating Clinical, Community, and Policy Perspectives on HPV Vaccination. Annual Review of Public Health Under review.

[18]. Mullen PD, Allen JD, Glanz K, Fernandez ME, Bowen DJ, Pruitt SL, et al. Measures used in studies of informed decision making about cancer screening: a systematic review. Ann Behav Med 2006;32(3):188-201. [PubMed: 17107291]

[19]. National Cancer Institute. Health Behavior and Constructs: Theory Measurement and Research. 2009

[20]. Janz NK, Becker MH. The Health Belief Model: a decade later. Health Educ Q 1984;11(1):1-47. [PubMed: 6392204]

[21]. Ajzen, I. The social psychology of decision making. In: Kruglanski, ETHAW., editor. Social Psychology: Handbook of Basic Principles. Academic Press; New York: 1996. p. 297-328.

[22]. Bandura, A. Self-efficacy: The exercise of control. Freeman/Times Books/ Henry Holt \& Co; New York, NY: 1997.

[23]. Bertram C, Niederhuaser VP. Uncertain knowledge of a certain virus: Human papillomavirus and abnormal pap smears: An internet survey of knowledge and beliefs among a university population in Hawaii. American Journal of Health Education 2008;39(1):15-24.

[24]. Denny-Smith T, Bairan A, Page MC. A survey of female nursing students' knowledge, health beliefs, perceptions of risk, and risk behaviors regarding human papillomavirus and cervical cancer. J Am Acad Nurse Pract 2006;18(2):62-9. [PubMed: 16460412]

[25]. Fazekas KI, Brewer NT, Smith JS. HPV vaccine acceptability in a rural Southern area. J Womens Health (Larchmt) 2008;17(4):539-48. [PubMed: 18370586]

[26]. Holcomb B, Bailey JM, Crawford K, Ruffin MTt. Adults' knowledge and behaviors related to human papillomavirus infection. J Am Board Fam Pract 2004;17(1):26-31. [PubMed: 15014049]

[27]. Ramirez JE, Ramos DM, Clayton L, Kanowitz S, Moscicki AB. Genital human papillomavirus infections: knowledge, perception of risk, and actual risk in a nonclinic population of young women. J Womens Health 1997;6(1):113-21. [PubMed: 9065380]

[28]. Wang J, Simoni PS, Wu Y. Human papillomavirus in rural adolescent females: Knowledge, protected sex, sexual risk behaviors. Online Journal of Rural Nursing and Health Care 2006;6(1): 74-88.

[29]. Yacobi E, Tennant C, Ferrante J, Pal N, Roetzheim R. University students' knowledge and awareness of HPV. Prev Med 1999;28(6):535-41. [PubMed: 10404550]

[30]. Moreira ED Jr. Oliveira BG, Ferraz FM, Costa S, Costa Filho JO, Karic G. Knowledge and attitudes about human papillomavirus, Pap smears, and cervical cancer among young women in Brazil: implications for health education and prevention. Int J Gynecol Cancer 2006;16(2):599_ 603. [PubMed: 16681732]

[31]. Ogilvie GS, Remple VP, Marra F, McNeil SA, Naus M, Pielak KL, et al. Parental intention to have daughters receive the human papillomavirus vaccine. Cmaj 2007;177(12):1506-12. [PubMed: 18056599]

[32]. Waller J, Marlow LA, Wardle J. The association between knowledge of HPV and feelings of stigma, shame and anxiety. Sex Transm Infect 2007;83(2):155-9. [PubMed: 17098767]

[33]. Kahn JA, Rosenthal SL, Jin Y, Huang B, Namakydoust A, Zimet GD. Rates of human papillomavirus vaccination, attitudes about vaccination, and human papillomavirus prevalence in young women. Obstet Gynecol 2008;111(5):1103-10. [PubMed: 18448742]

[34]. Sperber NR, Brewer NT, Smith JS. Influence of parent characteristics and disease outcome framing on HPV vaccine acceptability among rural, Southern women. Cancer Causes Control 2008;19(1):115-8. [PubMed: 17952620]

[35]. Gerend MA, Shepherd JE, Monday KA. Behavioral frequency moderates the effects of message framing on HPV vaccine acceptability. Ann Behav Med 2008;35(2):221-9. [PubMed: 18347893] 
[36]. Gerend MA, Shepherd JE. Using message framing to promote acceptance of the human papillomavirus vaccine. Health Psychol 2007;26(6):745-52. [PubMed: 18020847]

[37]. Benning BR, Lund MR. Patient knowledge about human papillomavirus and relationship to history of abnormal Papanicolaou test results. J Low Genit Tract Dis 2007;11(1):29-34. [PubMed: 17194948]

[38]. Donders GG, Gabrovska M, Bellen G, Van Keirsbilck J, Van Den Bosch T, Riphagen I, et al. Knowledge of cervix cancer, human papilloma virus (HPV) and HPV vaccination at the moment of introduction of the vaccine in women in Belgium. Arch Gynecol Obstet 2008;277(4):291-8. [PubMed: 17965870]

[39]. Dinh TA, Rosenthal SL, Doan ED, Trang T, Pham VH, Tran BD, et al. Attitudes of mothers in Da Nang, Vietnam toward a human papillomavirus vaccine. J Adolesc Health 2007;40(6):55963. [PubMed: 17531763]

[40]. Anderson-Ellstrom A, Milsom I. Knowledge about the prevention of sexually transmitted diseases: a longitudinal study of young women from 16-23 years of age. Sex Transm Infect 2002;78(5):339-41. [PubMed: 12407234]

[41]. Applegate T, Jones I. College Students' Knowledge of the Connection between HPV and Cervical Cancer. Health Education Monograph Series: Student Monograph 2002;19(2):1-5.

[42]. Baer H, Allen S, Braun L. Knowledge of human papillomavirus infection among young adult men and women: implications for health education and research. J Community Health 2000;25(1):67-78. [PubMed: 10706210]

[43]. Boardman LA, Cooper AS, Clark M, Weitzen S, Whiteley JA, Peipert JF. HPV, cervical neoplasia and smoking: knowledge among colposcopy patients. J Reprod Med 2004;49(12):96572. [PubMed: 15656213]

[44]. Chan SS, Cheung TH, Lo WK, Chung TK. Women's attitudes on human papillomavirus vaccination to their daughters. J Adolesc Health 2007;41(2):204-7. [PubMed: 17659226]

[45]. Dell DL, Chen H, Ahmad F, Stewart DE. Knowledge about human papillomavirus among adolescents. Obstet Gynecol 2000;96(5 Pt 1):653-6. [PubMed: 11042295]

[46]. D'Urso J, Thompson-Robinson M, Chandler S. HPV knowledge and behaviors of black college students at a historically black university. J Am Coll Health 2007;56(2):159-63. [PubMed: 17967762]

[47]. Ferris DG, Waller JL, Owen A, Smith J. HPV vaccine acceptance among mid-adult women. J Am Board Fam Med 2008;21(1):31-7. [PubMed: 18178700]

[48]. Gerend MA, Magloire ZF. Awareness, knowledge, and beliefs about human papillomavirus in a racially diverse sample of young adults. J Adolesc Health 2008;42(3):237-42. [PubMed: 18295131]

[49]. Gerhardt CA, Pong K, Kollar LM, Hillard PJ, Rosenthal SL. Adolescents' knowledge of human papillomavirus and cervical dysplasia. J Pediatr Adolesc Gynecol 2000;13(1):15-20. [PubMed: 10742668]

[50]. Giles M, Garland S. A study of women's knowledge regarding human papillomavirus infection, cervical cancer and human papillomavirus vaccines. Aust N Z J Obstet Gynaecol 2006;46(4): 311-5. [PubMed: 16866792]

[51]. Gudmundsdottir T, Tryggvadottir L, Allende M, Mast TC, Briem H, Sigurdsson K. Eligibility and willingness of young Icelandic women to participate in a HPV vaccination trial. Acta Obstet Gynecol Scand 2003;82(4):345-50. [PubMed: 12716319]

[52]. Hanisch R, Gustat J, Hagensee ME, Baena A, Salazar JE, Castro MV, et al. Knowledge of Pap screening and human papillomavirus among women attending clinics in Medellin, Colombia. Int J Gynecol Cancer 2008;18(5):1020-6. [PubMed: 18021221]

[53]. Hausdorf K, Newman B, Whiteman D, Aitken J, Frazer I. HPV vaccination: what do Queensland parents think? Aust N Z J Public Health 2007;31(3):288-9. [PubMed: 17682227]

[54]. Kahn JA, Rosenthal SL, Hamann T, Bernstein DI. Attitudes about human papillomavirus vaccine in young women. Int J STD AIDS 2003;14(5):300-6. [PubMed: 12803935]

[55]. Kwan TT, Chan KK, Yip AM, Tam KF, Cheung AN, Young PM, et al. Barriers and facilitators to human papillomavirus vaccination among Chinese adolescent girls in Hong Kong: a qualitative-quantitative study. Sex Transm Infect 2008;84(3):227-32. [PubMed: 18256106] 
[56]. Lambert EC. College students' knowledge of human papillomavirus and effectiveness of a brief educational intervention. J Am Board Fam Pract 2001;14(3):178-83. [PubMed: 11355049]

[57]. McPartland TS, Weaver BA, Lee SK, Koutsky LA. Men's perceptions and knowledge of human papillomavirus (HPV) infection and cervical cancer. J Am Coll Health 2005;53(5):225-30. [PubMed: 15813233]

[58]. Lazcano-Ponce E, Rivera L, Arillo-Santillan E, Salmeron J, Hernandez-Avila M, Munoz N. Acceptability of a human papillomavirus (HPV) trial vaccine among mothers of adolescents in Cuernavaca, Mexico. Archives of Medical Research 2001;32(3):243-47. [PubMed: 11395192]

[59]. Le T, Hicks W, Menard C, Boyd D, Hewson T, Hopkins L, et al. Human papilloma virus testing knowledge and attitudes among women attending colposcopy clinic with ASCUS/LGSIL pap smears. J Obstet Gynaecol Can 2004;26(9):788-92. [PubMed: 15361273]

[60]. Lenselink CH, Gerrits MM, Melchers WJ, Massuger LF, van Hamont D, Bekkers RL. Parental acceptance of Human Papillomavirus vaccines. Eur J Obstet Gynecol Reprod Biol 2008;137(1): 103-7. [PubMed: 17368910]

[61]. Marshall H, Ryan P, Roberton D, Baghurst PA. A cross-sectional survey to assess community attitudes to introduction of Human papillomavirus vaccine. Aust N Z J Public Health 2007;31(3): 235-42. [PubMed: 17679241]

[62]. Moreira ED Jr. de Oliveira BG, Neves RC, Costa S, Karic G, Filho JO. Assessment of knowledge and attitudes of young uninsured women toward human papillomavirus vaccination and clinical trials. J Pediatr Adolesc Gynecol 2006;19(2):81-7. [PubMed: 16624694]

[63]. Pitts M, Clarke T. Human papillomavirus infections and risks of cervical cancer: what do women know? Health Educ Res 2002;17(6):706-14. [PubMed: 12507346]

[64]. Pitts MK, Dyson SJ, Rosenthal DA, Garland SM. Knowledge and awareness of human papillomavirus (HPV): attitudes towards HPV vaccination among a representative sample of women in Victoria, Australia. Sex Health 2007;4(3):177-80. [PubMed: 17931530]

[65]. Pruitt SL, Parker PA, Peterson SK, Le T, Follen M, Basen-Engquist K. Knowledge of cervical dysplasia and human papillomavirus among women seen in a colposcopy clinic. Gynecol Oncol 2005;99(3 Suppl 1):S236-44. [PubMed: 16150483]

[66]. Saules KK, Vannest NO, Mehringer AM, Pomerleau CS, Lee K, Opipari AW Jr. et al. Actual versus perceived risk of cervical cancer among college women smokers. J Am Coll Health 2007;55(4):207-13. [PubMed: 17319326]

[67]. Tider DS, Parsons JT, Bimbi DS. Knowledge of human papillomavirus and effects on sexual behaviour of gay/bisexual men: a brief report. International Journal of Sexually Transmitted Diseases and AIDS 2005;16:707-08.

[68]. Tiro JA, Meissner HI, Kobrin S, Chollette V. What do women in the U.S. know about human papillomavirus and cervical cancer? Cancer Epidemiol Biomarkers Prev 2007;16(2):288-94. [PubMed: 17267388]

[69]. Vail-Smith K, White DM. Risk level, knowledge, and preventive behavior for human papillomaviruses among sexually active college women. J Am Coll Health 1992;40(5):227-30. [PubMed: 1315349]

[70]. Verhoeven V, Baay M, Colliers A, Verster A, Van Royen P, Avonts D, et al. The male factor in cervical carcinogenesis: a questionnaire study of men's awareness in primary care. Prev Med 2006;43(5):389-93. [PubMed: 16872669]

[71]. Waller J, McCaffery K, Wardle J. Beliefs about the risk factors for cervical cancer in a British population sample. Prev Med 2004;38(6):745-53. [PubMed: 15193894]

[72]. Waller J, McCaffery K, Forrest S, Szarewski A, Cadman L, Wardle J. Awareness of human papillomavirus among women attending a well woman clinic. Sex Transm Infect 2003;79(4): 320-2. [PubMed: 12902585]

[73]. Wetzel C, Tissot A, Kollar LM, Hillard PA, Stone R, Kahn JA. Development of an HPV educational protocol for adolescents. J Pediatr Adolesc Gynecol 2007;20(5):281-7. [PubMed: 17868894]

[74]. Ogilvie GS, Remple VP, Marra F, McNeil SA, Naus M, Pielak K, et al. Intention of parents to have male children vaccinated with the human papillomavirus vaccine. Sex Transm Infect 2008;84(4):318-23. [PubMed: 18445636] 
[75]. Pitts MK, Fox C, Willis J, Anderson J. What Do Gay Men Know About Human Papillomavirus? Australian Gay Men's Knowledge and Experience of Anal Cancer Screening and Human Papillomavirus. Sexually Transmitted Diseases 2007;34(3):170-73. [PubMed: 16837830]

[76]. Stark A, Gregoire L, Pilarski R, Zarbo A, Gaba A, Lancaster WD. Human papillomavirus, cervical cancer and women's knowledge. Cancer Detect Prev 2008;32(1):15-22. [PubMed: 18406069]

[77]. Hoover DR, Carfioli B, Moench EA. Attitudes of adolescent/young adult women toward human papillomavirus vaccination and clinical trials. Health Care Women Int 2000;21(5):375-91. [PubMed: 11261108]

[78]. Hopenhayn C, Christian A, Christian WJ, Schoenberg NE. Human papillomavirus vaccine: knowledge and attitudes in two Appalachian Kentucky counties. Cancer Causes Control 2007;18(6):627-34. [PubMed: 17497223]

[79]. Perez-Contreras I, Allen B, Ruiz-Velasco S, Schiavon-Errnani R, Cruz-Valdez A, Hernandez C, et al. Levels and correlates of knowledge about cancer risk factors among 13,293 public school students in Morelos, Mexico. Prev Med 2004;39(2):286-99. [PubMed: 15226037]

[80]. Baykal C, Al A, Ugur MG, Cetinkaya N, Attar R, Arioglu P. Knowledge and interest of Turkish women about cervical cancer and HPV vaccine. Eur J Gynaecol Oncol 2008;29(1):76-9. [PubMed: 18386470]

[81]. Constantine NA, Jerman P. Acceptance of human papillomavirus vaccination among Californian parents of daughters: a representative statewide analysis. J Adolesc Health 2007;40(2):108-15. [PubMed: 17259050]

[82]. Marlow LA, Waller J, Wardle J. Sociodemographic predictors of HPV testing and vaccination acceptability: results from a population-representative sample of British women. J Med Screen 2008;15(2):91-6. [PubMed: 18573777]

[83]. Marlow LA, Waller J, Wardle J. Trust and experience as predictors of HPV vaccine acceptance. Hum Vaccin 2007;3(5):171-5. [PubMed: 17622801]

[84]. Slomovitz BM, Sun CC, Frumovitz M, Soliman PT, Schmeler KM, Pearson HC, et al. Are women ready for the HPV vaccine? Gynecological Oncology 2006;103(1):151-54.

[85]. Woodhall SC, Lehtinen M, Verho T, Huhtala H, Hokkanen M, Kosunen E. Anticipated acceptance of HPV vaccination at the baseline of implementation: a survey of parental and adolescent knowledge and attitudes in Finland. J Adolesc Health 2007;40(5):466-9. [PubMed: 17448408]

[86]. Zimet GD, Mays RM, Sturm LA, Ravert AA, Perkins SM, Juliar BE. Parental attitudes about sexually transmitted infection vaccination for their adolescent children. Arch Pediatr Adolesc Med 2005;159(2):132-7. [PubMed: 15699306]

[87]. Crosby R, Schoenberg N, Hopenhayn C, Moore G, Melhan W. Correlates of intent to be vaccinated against human papillomavirus: an exploratory study of college-aged women. Sex Health 2007;4(1):71-3. [PubMed: 17382042]

[88]. Zimet GD, Mays RM, Winston Y, Kee R, Dickes J, Su L. Acceptability of human papillomavirus immunization. J Womens Health Gend Based Med 2000;9(1):47-50. [PubMed: 10718505]

[89]. Ajzen I. The theory of planned behavior. Organizational Behavior and Human Decision processes 1991;50:179-211.

[90]. Waller J, Marlow LA, Wardle J. Mothers' attitudes towards preventing cervical cancer through human papillomavirus vaccination: A qualitative study. Cancer Epidemiology, Biomarkers and Prevention 2006;15(7):1257-61.

[91]. Eaton L, Kalichman S, Cain D, Cherry C, Pope H, Fuhrel A, et al. Perceived prevalence and risks for human papillomavirus (HPV) infection among women who have sex with women. J Womens Health (Larchmt) 2008;17(1):75-83. [PubMed: 18240984]

[92]. Ajzen, I. Attitudes, personality, and behavior. 2nd ed.. Open University Press (McGraw-Hill); Milton-Keynes, England: 2005.

[93]. Koulova A, Tsui J, Irwin K, Van Damme P, Biellik R, Aguado MT. Country recommendations on the inclusion of HPV vaccines in national immunization programmes among high-income countries, June 2006-January 2008. Vaccine 2008;26(51):6529-41. [PubMed: 18805453] 
[94]. Mathews C, Restivo A, Raker C, Weitzen S, Disilvestro P. Willingness of gynecologic cancer patients to participate in clinical trials. Gynecol Oncol 2009;112(1):161-65. [PubMed: 18952272]

[95]. Ding E, Powe NR, Manson JE, Sherber NS, Braunstein JB. Sex differences in perceived risks, distrust, and willingness to participate in clinical trials: a randomized study of cardiovascular prevention trials. Arch Intern Med 2007;167(9):905-12. [PubMed: 17502531]

[96]. Moher D, Jones A, Lepage L. Use of the CONSORT statement and quality of reports of randomized trials: a comparative before-and-after evaluation. Jama 2001;285(15):1992-5. [PubMed: 11308436]

[97]. Plint AC, Moher D, Morrison A, Schulz K, Altman DG, Hill C, et al. Does the CONSORT checklist improve the quality of reports of randomised controlled trials? A systematic review. Med J Aust 2006;185(5):263-7. [PubMed: 16948622]

[98]. Vlahov D. Transparent Reporting of Evaluations with Nonrandomized Designs (TREND). J Urban Health 2004;81(2):163-4. [PubMed: 15136648]

[99]. Vandenbroucke JP, von Elm E, Altman DG, Gotzsche PC, Mulrow CD, Pocock SJ, et al. Strengthening the Reporting of Observational Studies in Epidemiology (STROBE): explanation and elaboration. Ann Intern Med 2007;147(8):W163-94. [PubMed: 17938389]

[100]. Watson M, Saraiya M, Benard V, Coughlin SS, Flowers L, Cokkinides V, et al. Burden of cervical cancer in the United States, 1998-2003. Cancer 2008;113(10 Suppl):2855-64. [PubMed: 18980204]

[101]. Fernandez M, Allen JD, Mistrey R, Kahn JA. Integrating Clinical, Community, and Policy Perspectives on HPV Vaccination. Under review.

[102]. McLeroy KR, Bibeau D, Steckler A, Glanz K. An ecological perspective on health promotion programs. Health Educ Q 1988;15(4):351-77. [PubMed: 3068205]

[103]. O'Connor AM, Tugwell P, Wells GA, Elmslie T, Jolly E, Hollingworth G, et al. A decision aid for women considering hormone therapy after menopause: decision support framework and evaluation. Patient Educ Couns 1998;33(3):267-79. [PubMed: 9731164]

[104]. Bermudez, J. Decision Theory and Rationality. Oxford University Press; USA: 2009.

[105]. Durvasula, Ramani S.; Regan, Pamela C.; Ureno, Oscar; Howell, Lisa. Predictors of cervical cancer screening in Asian and Latina university students. 2008

[106]. Baldwin SB, Wallace DR, Papenfuss MR, Abrahamsen M, Vaught LC, Giuliano AR. Condom use and other factors affecting penile human papillomavirus detection in men attending a sexually transmitted disease clinic. Sexually Transmitted Diseases 2004;31(10):601-07. [PubMed: 15388997]

[107]. Zimet GD, Shew ML, Kahn JA. Appropriate use of cervical cancer vaccine. Annu Rev Med 2008;59:223-36. [PubMed: 18186704]

[108]. Newman P, Lee SJ, Duan N, Rudy E, Nakazono TK, Boscardin J, et al. Preventive HIV Vaccine Acceptability and Behavioral Risk Compensation among a Random Sample of High-Risk Adults in Los Angeles (LA VOICES). Health Serv Res. 2009 Epub ahead of print.

[109]. Kakinami L, Newman PA, Lee SJ, Duan N. Differences in HIV vaccine acceptability between genders. AIDS Care 2008;20(5):542-6. [PubMed: 18484322]

[110]. Aday, LA. A comprehensive guide. 3rd ed.. Jossey Bass Publishers; San Francisco, CA: 2006. Designing and conducting health surveys.

[111]. Willis, G. Cognitive Interviewing: A Tool for Improving Questionnaire Design. Sage Publications; Thousand Oaks, CA: 2005.

[112]. Richman A, Coronado GD, Arnold LD, Fernandez ME, Glenn BA, Allen JD, et al. Cognitive Testing of HPV Vaccine Survey Items for Parents of Adolescent Girls. Under review.

[113]. Institute of Medicine. Financing Vaccines in the 21st Century: Assuring Access and Availability. National Academies Press; Washington, DC: 2004.

[114]. MMWR. National, State, and Local Area Vaccination Coverage Among Adolescents Aged 13--17 Years --- United States. MMWR 2008;58(36):997-1001.

[115]. Neubrand T, Breitkopf CR, Rupp R, Breitkopf D, Rosenthal SL. Factors associated with completion of the Human Papillomavirus vaccine series. Clinical Pediatrics 2009;48(9):966-69. [PubMed: 19483128] 
[116]. Downs L, Smith JS, Scarinci I, Flowers L, Parham G. The disparity of cervical cancer in diverse populations. Gynecol Oncol 2008;109:S22-30. [PubMed: 18482555]

[117]. Guiliano A, Salmon D. The case for a gender-neutral (universal) human papillomavirus vaccination policy in the US: point. Cancer Epidemiol Biomarkers Prev 2008;17:809. [PubMed: 18398021] 


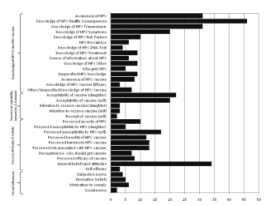

Figure 1.

Number of studies that measured each construct $(\mathrm{N}=79)$ 
Table 1

Characteristics of the 79 Included Studies

\begin{tabular}{|c|c|c|}
\hline & $\mathbf{n}$ & $\%$ \\
\hline \multicolumn{3}{|l|}{ Study design } \\
\hline Randomized controlled trial & 3 & 4 \\
\hline Before-after one group trial & 6 & 8 \\
\hline Cross-sectional & 69 & 87 \\
\hline Other & 2 & 3 \\
\hline \multicolumn{3}{|l|}{ Study location } \\
\hline U.S. & 41 & 52 \\
\hline Non-U.S. ${ }^{*}$ & 36 & 46 \\
\hline Not specified & 2 & 3 \\
\hline \multicolumn{3}{|l|}{ Study setting ${ }^{*}$} \\
\hline Population-based setting & 26 & 33 \\
\hline Health care setting & 33 & 42 \\
\hline School setting & 7 & 9 \\
\hline College setting & 24 & 30 \\
\hline Other & 6 & 8 \\
\hline \multicolumn{3}{|l|}{ Data collection method } \\
\hline Self-administered survey & 53 & 67 \\
\hline Interviewer-administered survey & 20 & 25 \\
\hline Online survey & 2 & 3 \\
\hline Other & 4 & 5 \\
\hline \multicolumn{3}{|l|}{ Sample* } \\
\hline Parents & 17 & 22 \\
\hline Women & 46 & 58 \\
\hline Men & 4 & 5 \\
\hline Women and men & 14 & 18 \\
\hline Adolescent girls $(<18)$ & 22 & 28 \\
\hline \multicolumn{3}{|l|}{ Proportion of sample reported to be non-Hispanic White } \\
\hline $0 \%-25 \%$ & 11 & 14 \\
\hline $26 \%-50 \%$ & 13 & 17 \\
\hline $51 \%-75 \%$ & 9 & 11 \\
\hline $75 \%-100 \%$ & 26 & 33 \\
\hline \multicolumn{3}{|l|}{ Sampling method } \\
\hline Random & 19 & 24 \\
\hline Convenience & 51 & 65 \\
\hline Other & 10 & 13 \\
\hline
\end{tabular}

Vaccine. Author manuscript; available in PMC 2011 May 28. 


\begin{tabular}{|l|l|l|}
\hline & n & $\%$ \\
\hline Sample size & & \\
$<100$ & 10 & 13 \\
$101-500$ & 46 & 58 \\
$501-1000$ & 12 & 15 \\
$>1000$ & 12 & 15 \\
\hline Date of study & & \\
Pre vaccine licensure & 53 & 67 \\
Post vaccine licensure & 13 & 17 \\
Not stated & 14 & 18 \\
\hline
\end{tabular}

Note. Some categories are not mutually exclusive, as some studies were conducted in multiple settings or with multiple sample types or theoretical models.

* Non-US countries were Australia (5 studies); Belgium (3); Brazil (2); Canada ( $\mathrm{n=4);}$ Columbia ( $\mathrm{n}=1$ ); Finland ( $\mathrm{n}=1$ ); Germany ( $\mathrm{n}=1$ ): Hong Kong $(\mathrm{n}=2)$; Iceland $(\mathrm{n}=1)$; Mexico $(\mathrm{n}=2)$; Netherlands $(\mathrm{n}=1)$; Sweden $(\mathrm{n}=1)$; Turkey $(\mathrm{n}=1)$; UK $(\mathrm{n}=10)$; and Vietnam $(\mathrm{n}=1)$. 
Table 2

Characteristics of 25 studies that reported reliability or validity information

\begin{tabular}{|c|c|c|c|c|}
\hline Study & $\begin{array}{l}\text { Construct (number of items in } \\
\text { measure)* }\end{array}$ & Reliability & Validity & Sample Characteristics \\
\hline Benning, 2007[37] & $\begin{array}{l}\text { HPV Awareness (1); know-ledge } \\
\text { of HPV health conse-quences (4), } \\
\text { transmission (5), symptoms (2), } \\
\text { treatment (1), unspecified HPV } \\
\text { Knowledge (1) }\end{array}$ & NR & $\begin{array}{l}\text { Pre-tested with } \\
\text { people outside of } \\
\text { health care for } \\
\text { clarity, uniformity } \\
\text { of interpretation }\end{array}$ & $\begin{array}{l}363 \text { women age } 15-74 \\
\text { (mean=29); } 41 \% \text { White, } 28 \% \\
\text { Black, } 24 \% \text { Hispanic, } 3 \% \text { Asian, } \\
2 \% \text { Other }\end{array}$ \\
\hline Bertram, 2008[23] & $\begin{array}{l}\text { Knowledge HPV health } \\
\text { consequences (3), transmission (1), } \\
\text { symptoms (2), DNA test (2), } \\
\text { treatment (2), un-specified HPV } \\
\text { knowledge (3) }\end{array}$ & $\alpha=0.85$ & $\begin{array}{l}\text { Face validity: } \\
\text { expert panel } \\
\text { (faculty, students) } \\
\text { Content validity: } \\
\text { Reviewed by health } \\
\text { care providers, } \\
\text { compared with } \\
\text { published health ed } \\
\text { materials }\end{array}$ & $\begin{array}{l}492 \text { college students, } 75 \% \\
\text { female; } 49 \% \text { Asian, } 19 \% \text { White, } \\
12 \% \text { Filipino, } 11 \% \text { Hawaiian, } 4 \% \\
\text { Hispanic }\end{array}$ \\
\hline Brabin 2006[5] & $\begin{array}{l}\text { Knowledge HPV health } \\
\text { consequences (3), transmission (3), } \\
\text { symptoms (1), risk factors (1), } \\
\text { treatment (1), vaccine efficacy (1); } \\
\text { acceptability daughter (1), } \\
\text { perceived risk (3) and perceived } \\
\text { efficacy (4) of the vaccine }\end{array}$ & Not reported & $\begin{array}{l}\text { Three rounds of } \\
\text { validation (method } \\
\text { not reported) }\end{array}$ & $\begin{array}{l}317 \text { parents of } 11-12 \text { yr olds; } \\
72 \% \text { parents of girls; } 65 \% \text { White, } \\
17 \% \text { Black, } 12 \% \text { Indian, } 4 \% \\
\text { Other, } 2 \%\end{array}$ \\
\hline Davis 2004[8] & $\begin{array}{l}\text { Knowledge HPV health } \\
\text { consequences (5), transmission } \\
\text { (NR), treatment (1), other/ } \\
\text { unspecified knowledge of HPV (1) } \\
\text { and HPV vaccine (NR); } \\
\text { acceptability-daughter (1); } \\
\text { perceived benefits, (2) perceived } \\
\text { risk, and perceived efficacy (5) of } \\
\text { the vaccine (3); general beliefs / } \\
\text { attitudes (11) }\end{array}$ & Not reported & $\begin{array}{l}2 \text { rounds of pilot } \\
\text { testing with focus } \\
\text { group of } 7 \text { parents } \\
\text { of } 10-15 \text { year old } \\
\text { girls }\end{array}$ & $\begin{array}{l}506 \text { parents of } 10-15 \text { year olds, } \\
89 \% \text { female, } 51 \% \text { White, } 45 \% \\
\text { Black, } 4 \% \text { Other }\end{array}$ \\
\hline \multirow[t]{3}{*}{ Dempsey2006[6] } & Intention (daughter) (3) & $\alpha=0.83$ & \multirow[t]{3}{*}{ Not reported } & \multirow{3}{*}{$\begin{array}{l}840 \text { Parents/primary caregivers of } \\
8-12 \text { year olds, } 84 \% \text { female, } \\
\text { ethnically, culturally, over } 25 \\
\text { racial/ethnic groups, } 75 \% \text { White, } \\
5 \% \text { Black, } 11 \% \text { Asian, } 9 \% \text { other } \\
\text { or unreported (baseline survey } \\
\text { participants); } 78 \% \text { White, } 4 \% \\
\text { Black, } 11 \% \text { Asian, } 7 \% \text { other or } \\
\text { unreported (information sheet } \\
\text { participants) }\end{array}$} \\
\hline & $\begin{array}{l}\text { Perceived benefits ( } 3 \text { ) and barriers } \\
\text { (3); susceptibility (daughter) (3); } \\
\text { general beliefs /attitudes (3) }\end{array}$ & $\alpha=0.68-0.78$ & & \\
\hline & $\begin{array}{l}\text { Perceived severity ( } 3 \text { ); subjective } \\
\text { norms ( } 2) \text {; normative beliefs ( } 1 \text { ) }\end{array}$ & $\alpha=0.20-0.27$ & & \\
\hline Denney-Smith, 2006[24] & $\begin{array}{l}\text { Knowledge HPV health } \\
\text { consequences (3) and transmission } \\
\text { (1); perceived severity (2) and } \\
\text { susceptibility (self) (5); general } \\
\text { beliefs / attitudes (5) }\end{array}$ & $\begin{array}{l}\text { Knowledge } \\
\text { HPV health } \\
\text { consequences } \\
\text { (3) } \alpha=0.95 ; \& \\
\text { transmission } \\
\text { (1); perceived } \\
\text { severity (2) \& } \\
\text { susceptibility } \\
\text { (self) (5) } \\
\alpha=0.95 ; \\
\text { general } \\
\text { beliefs / } \\
\text { attitudes (5) } \\
\text { Test-retest } \\
\text { reliability } \\
\text { coefficient } \\
0.90\end{array}$ & $\begin{array}{l}\text { Content validity } \\
\text { reviewed by expert } \\
\text { panel and pilot } \\
\text { tested (not specified } \\
\text { among whom) }\end{array}$ & $\begin{array}{l}240 \text { female nursing students aged } \\
19-58\end{array}$ \\
\hline Dinh, 2007[39] & $\begin{array}{l}\text { Awareness of HPV (1); } \\
\text { acceptability-daughter (1); } \\
\text { perceived susceptibility-daughter } \\
\text { (1); perceived efficacy (1); general } \\
\text { beliefs / attitudes (1) }\end{array}$ & Not reported & $\begin{array}{l}\text { Native Vietnamese } \\
\text { speakers reviewed } \\
\text { the instrument to } \\
\text { ascertain } \\
\text { correctness and }\end{array}$ & $\begin{array}{l}181 \text { Vietnamese mothers of } 10- \\
18 \text { year old girls, age range } 26- \\
60 \text {, mean age } 42\end{array}$ \\
\hline
\end{tabular}




\begin{tabular}{|c|c|c|c|c|}
\hline Study & $\begin{array}{l}\text { Construct (number of items in } \\
\text { measure)* }\end{array}$ & Reliability & Validity & Sample Characteristics \\
\hline & & & $\begin{array}{l}\text { clarity in content, } \\
\text { context, and tone }\end{array}$ & \\
\hline Donders, 2008[38] & $\begin{array}{l}\text { Awareness of HPV vaccine (1); } \\
\text { knowledge HPV other (1), other/ } \\
\text { unspecified knowledge of HPV } \\
\text { vaccine (1); acceptability-daughter } \\
\text { (1), acceptability-self (2); } \\
\text { perceived barriers (3), risk of the } \\
\text { vaccine (2); perceptions re: who } \\
\text { should get the vaccine (3) }\end{array}$ & Not reported & $\begin{array}{l}\text { Questions were } \\
\text { read by } 12 \text { women } \\
\text { of varying } \\
\text { education levels to } \\
\text { ensure they were } \\
\text { understood by all }\end{array}$ & $\begin{array}{l}372 \text { women, mean age } 36,79 \% \\
\text { parents, } 51 \% \text { parents of daughters }\end{array}$ \\
\hline \multirow[t]{3}{*}{ Fazekas, 2008[25] } & Acceptability-daughter (3), self (3) & $\alpha=0.89$ & \multirow[t]{3}{*}{ Not reported } & \multirow{3}{*}{$\begin{array}{l}146 \text { rural women, mean age } 42, \\
62 \% \text { Black, } 32 \% \text { white, } 2 \% \text { other } \\
4 \% \text { unreported, } 85 \% \text { mothers }\end{array}$} \\
\hline & Perceived benefits (6) & $\alpha=0.7-0.94$ & & \\
\hline & Perceived barriers (3) & $\alpha=0.79$ & & \\
\hline Gerend, 2007[36] & Acceptability-(self (5) & $\alpha=0.96$ & Not reported & $\begin{array}{l}121 \text { female college students age } \\
18-25 \text { (mean age } 19), 85 \% \\
\text { White, } 10 \% \text { Black, } 5 \% \\
\text { unreported, (12\% of Whites } \\
\text { reported Hispanic ethnicity) }\end{array}$ \\
\hline Gerend, 2007[7] & Acceptability-(self (4) & $\alpha=0.90$ & Not reported & $\begin{array}{l}58 \text { women } 1-50 \text {, mean age } 26 \text {, } \\
29 \% \text { White, } 59 \% \text { Black, } 12 \% \\
\text { other }\end{array}$ \\
\hline \multirow[t]{6}{*}{ Gerend, 2008[35] } & Acceptability-self (5) & $\alpha=0.97$ & \multirow[t]{6}{*}{ Not reported } & \multirow{6}{*}{$\begin{array}{l}237 \text { female college students age } \\
18-26 \text {, mean age } 19,76 \% \text { White, } \\
13 \% \text { Black, } 2 \% \text { Asian, } 9 \% \text { mixed } \\
\text { or other ( } 8 \% \text { of Whites reported } \\
\text { Hispanic ethnicity) }\end{array}$} \\
\hline & General beliefs / attitudes (2) & $\alpha=0.94$ & & \\
\hline & Perceived severity (4) & $\alpha=0.90$ & & \\
\hline & Perceived susceptibility-self (2) & $\alpha=0.94$ & & \\
\hline & Perceived benefits (3) & $\alpha=0.86$ & & \\
\hline & Perceived barriers (2) & $\alpha=0.90$ & & \\
\hline \multirow[t]{3}{*}{ Holcomb20 04[26] } & $\begin{array}{l}\text { Knowledge of HPV health } \\
\text { consequences (5) }\end{array}$ & $\alpha=0.92$ & \multirow{3}{*}{$\begin{array}{l}\text { Face \& construct } \\
\text { validity was } \\
\text { reported to be } \\
\text { "good", although } \\
\text { additional } \\
\text { information was not } \\
\text { available }\end{array}$} & \multirow{3}{*}{$\begin{array}{l}288 \text { men and women from under } \\
20 \text { to over } 46 \text {, sample primarily } \\
\text { female and White; } 77 \% \text { White, } \\
14 \% \text { Black, } 2 \% \text { Hispanic, 3\% } \\
\text { Asian, } 1 \% \text { other, 3\% unreported } \\
\text { (Family practice sample); 64\% } \\
\text { White, 9\% Black, } 7 \% \text { Hispanic, } \\
13 \% \text { Asian, } 1 \% \text { other, } 6 \% \\
\text { unreported (Student health clinic } \\
\text { sample) }\end{array}$} \\
\hline & $\begin{array}{l}\text { Knowledge of HPV risk factors } \\
\text { (14) }\end{array}$ & $\alpha=0.93$ & & \\
\hline & Knowledge of HPV symptoms (1) & $\alpha=0.92$ & & \\
\hline \multirow[t]{7}{*}{ Kahn, 2008[33] } & $\begin{array}{l}\text { Intention to receive vaccine -self- } \\
\text { (1) }\end{array}$ & $\alpha=0.82$ & \multirow[t]{7}{*}{ Not reported } & \multirow{7}{*}{$\begin{array}{l}409 \text { women aged } 13-26 \text {, mean } \\
\text { age } 19,29 \% \text { White, } 60 \% \text { Black, } \\
9 \% \text { other, } 2 \% \text { unreported }\end{array}$} \\
\hline & General beliefs and attitudes (28) & $\alpha=0.79-0.96$ & & \\
\hline & Perceived severity of HPV (5) & $\alpha=0.75-0.76$ & & \\
\hline & $\begin{array}{l}\text { Perceived susceptibility to HPV- } \\
\text { self (2) }\end{array}$ & $\alpha=0.77$ & & \\
\hline & Perceived benefits of vaccine (6) & $\alpha=0.65-0.82$ & & \\
\hline & Perceived barriers to vaccine (11) & $\alpha=0.66-0.82$ & & \\
\hline & Perceived risk of vaccine (4) & $\alpha=0.82$ & & \\
\hline Marlow, 2007[15] & $\begin{array}{l}\text { Awareness of HPV (1); } \\
\text { acceptability of vaccine-daughter } \\
\text { (1), perceived barriers (2) and } \\
\text { perceived risk of the vaccine (2); } \\
\text { general beliefs and attitudes (NR); } \\
\text { social norms (NR) }\end{array}$ & Not reported & Pilot focus groups & $\begin{array}{l}680 \text { mothers of } 8-4 \text { y.o. girls, } \\
\text { mean age } 41,92.6 \% \text { White }\end{array}$ \\
\hline
\end{tabular}




\begin{tabular}{|c|c|c|c|c|}
\hline Study & $\begin{array}{l}\text { Construct (number of items in } \\
\text { measure)* }\end{array}$ & Reliability & Validity & Sample Characteristics \\
\hline Marlow, 2007[83] & General beliefs and attitudes (NR) & $\alpha=0.66-0.76$ & Not reported & $\begin{array}{l}684 \text { mothers of at least } 1 \text { daughter } \\
\text { age } 8-14 \text {, mean age } 41,93 \% \\
\text { White }\end{array}$ \\
\hline Moreira, 2006[30] & $\begin{array}{l}\text { Knowledge of HPV health } \\
\text { consequences (1), transmission (1), } \\
\text { other knowledge (1); general } \\
\text { beliefs / attitudes (NR) }\end{array}$ & Not reported & $\begin{array}{l}\text { Face validation } \\
\text { assessed by health } \\
\text { survey experts }\end{array}$ & $\begin{array}{l}204 \text { women age } 16-23, \text { mean age } \\
20,2 \% \text { White, } 26 \% \text { Black, } 72 \% \\
\text { mixed ethnicity }\end{array}$ \\
\hline Ogilvie, 2007[31] & $\begin{array}{l}\text { Awareness of HPV (1); knowledge } \\
\text { of HPV transmission (1); perceived } \\
\text { benefits (2), risk of the (2), efficacy } \\
\text { of vaccine (2); general beliefs / } \\
\text { attitudes; subjective norms (5) }\end{array}$ & $\alpha \geq 0.60$ & Not reported & $\begin{array}{l}2083 \text { parents of children aged } 8- \\
18,74 \% \text { female, age range: } 19- \\
>60,83 \% \text { White, } 2 \% \text { Aboriginal, } \\
15 \% \text { other, } 65 \% \text { had daughters }\end{array}$ \\
\hline Ogilvie, 2008[74] & $\begin{array}{l}\text { Awareness of HPV (2); knowledge } \\
\text { of HPV transmission (2) }\end{array}$ & $\alpha=0.60$ & Not reported & $\begin{array}{l}2083 \text { parents of children aged } 8- \\
18,74 \% \text { female, age range: } 19- \\
>60,83 \% \text { White }\end{array}$ \\
\hline \multirow[t]{2}{*}{ Ramirez, 1997[27] } & Other knowledge (20) & $\alpha=0.60$ & \multirow[t]{2}{*}{ Not reported } & \multirow{2}{*}{$\begin{array}{l}110 \text { female college students } 18- \\
22, \text { mean age 20, 54\% White, } 6 \% \\
\text { Black, 23\% Asian, } 13 \% \\
\text { Hispanic, } 6 \% \text { Other }\end{array}$} \\
\hline & General beliefs and attitudes (NR) & $\alpha=0.89$ & & \\
\hline Sperber, 2008[34] & $\begin{array}{l}\text { Acceptability of vaccine-self [3], } \\
\text { daughter [3]) }\end{array}$ & $\alpha=0.89$ & $\begin{array}{l}\text { Pilot testing } \\
\text { including review by } \\
\text { experts and testing } \\
\text { with residents of } \\
\text { neighboring county }\end{array}$ & $\begin{array}{l}146 \text { women } 18-84 \text { (mean age } \\
42 \text { ), } 32 \% \text { White, } 62 \% \text { Black, } 6 \% \\
\text { other, } 62 \% \text { had daughters, } 19 \% \\
\text { had daughters } 11-16\end{array}$ \\
\hline Waller, 2007[32] & General beliefs / attitudes (17) & $\alpha=0.73-.90$ & Pilot testing & $\begin{array}{l}811 \text { female college students } 18- \\
30,68 \% \text { White, } 2 \% \text { Black, } 20 \% \\
\text { Asian, } 10 \% \text { Other }\end{array}$ \\
\hline Wang, 2006[28] & $\begin{array}{l}\text { Knowledge of HPV transmission } \\
\text { (10), symptoms (6), and other } \\
\text { knowledge (30) }\end{array}$ & $\alpha=0.77$ & Not reported & $\begin{array}{l}159 \text { rural female high school } \\
\text { students 14-20 (mean age 17), } \\
98 \% \text { White }\end{array}$ \\
\hline Yacobi, 1999[29] & Knowledge of HPV other (14) & $\alpha=0.93$ & $\begin{array}{l}\text { Construct validity } \\
\text { assessed, although } \\
\text { additional } \\
\text { information was not } \\
\text { available. }\end{array}$ & $\begin{array}{l}289 \text { college students, median age } \\
25,63 \% \text { female, } 81 \% \text { White, } 5 \% \\
\text { Black, } 7 \% \text { Hispanic, } 7 \% \text { Other }\end{array}$ \\
\hline
\end{tabular}

